\title{
Antifouling-Bacterial Potentials of Kenikir (Cosmos caudatus) and Bandotan (Ageratum conyzoides) Leaf Extracts in Freshwater Environment
}

\author{
Sesilia Rani Samudra ${ }^{1 *}$, Ren Fitriadi ${ }^{2}$ and Bintang Marhaeni ${ }^{3}$ \\ ${ }^{1}$ Aquatic Resources Management Study Program, Faculty of Fisheries and Marine Sciences, Jenderal \\ Soedirman University, Jl. Dr. Soeparno Sports Complex Soesilo Soedarman, Karangwangkal, \\ Purwokerto 53122, Indonesia \\ ${ }^{2}$ Aquaculture Study Program, Faculty of Fisheries and Marine Sciences, Jenderal Soedirman \\ University, Jl. Dr. Soeparno Sports Complex Soesilo Soedarman, Karangwangkal, Purwokerto \\ 53122, Indonesia \\ ${ }^{3}$ Marine Science Study Program, Faculty of Fisheries and Marine Sciences, Jenderal Soedirman \\ University, Jl. Dr. Soeparno Sports Complex Soesilo Soedarman, Karangwangkal, Purwokerto \\ 53122, Indonesia
}

*Correspondence :

sesiliarani@unsoed.ac.id

Received : 2020-10-19

Accepted : 2021-03-22

Keywords :

Antifouling, Cosmos caudatus, Ageratum conyzoides, Bacteria

\begin{abstract}
Biofouling refers to the attachment of organisms to the surface of an object submerged in water. It is often undesirable due to its detrimental effects, meanwhile, one way of managing biofouling is via antifouling. This study aims to examine the potential of kenikir (Cosmos caudatus) and bandotan (Ageratum conyzoides) leaves extracts as an alternative to natural antifouling. The research was conducted using the exploration method where the extract of both plants was examined in field and laboratory scales. Moreover, the extracts were mixed with paint without antifouling and then tested on a field scale by painting on wooden blocks. Observations were made by counting the number of microfouling in form of bacterial colonies attached to the painted wood surface by scraping the surface of the wood submerged in freshwater for one week. The results showed that the number of bacterial colonies with kenikir leaves extract was less than the bandotan extract. Moreover, based on the phytochemical analysis results, both kenikir and bandotan extracts contain alkaloids, steroids, tannins and saponins, however, the alkaloid content in kenikir leaf extract was higher compared to bandotan leaves. In conclusion, kenikir leaves extract has greater potential as an alternative source of antifouling compared to bandotan because the former has more bioactive content, especially alkaloid compounds.
\end{abstract}

\section{INTRODUCTION}

Biofouling is the accumulation or growth of unwanted organisms, plants, or animals on the surface of an object (natural or artificial) submerged in water such as bacteria, viruses, fungi, microalgae, protozoa, and meroplankton (Agostini et al., 2019; Fujita et al., 2015; Marhaeni, 2012). This occurs due to the adsorption of organic molecules on the surface of a hard substrate submerged in 
water, followed by bacterial colonization which produces Extracellular Polymer Substance (EPS) which forms biofilms (Agostini et al., 2019; Aykin et al., 2019). Meanwhile, organisms attached to watersubmerged materials tend to grow rapidly and cause weathering (on wood) or corrosion (on metal). Biofouling organisms often cause various problems that are detrimental to humans such as damage to ship structures, fish cultivation cages, fishing nets, and others (Aykin et al., 2019; Nakano and Strayer, 2014).

One way to solve biofouling problems is by using paints or coatings containing antifouling substances. This prevents the attachment of microorganisms; therefore, it provides effective protection in the long term. Furthermore, the main purpose of the antifouling application is to prevent the initial formation of micro fouling such as bacterial biofilms by preventing contact between organisms and substrate surface (Aykin et al., 2019; Romani, 2010).

Antifouling substances in paints or coatings commonly used nowadays contain heavy metal compounds such as TBT (Tri-n-Butyl Tin) (Guardiola et al., 2012; Wells and Sytsma, 2009). However, these compounds are not only toxic to biofouling organisms but also other organisms, including humans. Therefore, the production of antifouling coating paints is challenging for manufacturers to create and develop alternative natural materials to prevent water pollution from these toxic compounds. Furthermore, research and development on antifouling coating products that are environmentally friendly (natural) and non-toxic are becoming increasingly extensive (Aykin et al., 2019). Currently, the development of antifouling coatings using natural materials is still far from commercialization, however, studies are ongoing with the expectation of producing efficient and safe antifouling agents (Yebra et al., 2004).

Several previous studies regarding anti-fouling materials with natural ingredients have been carried out using bioactive compounds from plants. Meanwhile, Kenikir and bandotan are plants with secondary metabolites, therefore in theory, these plants are applicable as antifouling agents. The plant part used in making antifouling extracts are the leaves due to the composition of the secondary metabolites. Leaves, being the site of photosynthesis contain sugars and carbohydrates are used in the formation of secondary metabolites. This study aims to determine the type of plant extract with the most antifouling potential between kenikir (Cosmos caudatus) and bandotan (Ageratum conyzoides).

\section{METHODOLOGY}

\section{Place and Time}

This study was carried out in Embung Maron, Kebumen Village, Baturraden Sub-District, Banyumas Regency in August 2020.

\section{Research Materials}

The materials used in this study were the kenikir (C. caudatus) and bandotan (A. conyzoides) leaves, ethanol 96\% (maceration extraction); laban wooden blocks, non-antifouling black oil paint (apply antifouling paint); aquadest, chloroform, KI solution, $\mathrm{HgCl}_{2}, \mathrm{HCl}, \mathrm{FeCl}_{3}$, $\mathrm{CH}_{3} \mathrm{COOH}$ glacial, $\mathrm{H}_{2} \mathrm{SO}_{4}$ (phytochemical analysis); aquadest, plate count agar (MERCK) (total plate count). And the equipment used for this study was trays, blender, storage glass jars, rope, eye hook screws, 1,5-inch brushes, sterile cotton swabs, sample bottles, measuring cup, analytical balance (OHAUS, PA224, USA), rotary evaporator (BUCHI Rotavapor R-3, Switzerland), petri dish, test tubes (PYREX), micropipette 200-1.000 $\mu$, Bunsen burner, Lutron YK-2001PHA (TDS, DO, Temperature meter), Lutron PH-222 (pH meter).

\section{Research Design}

This study was conducted via the exploration method by making extracts from kenikir and bandotan leaves, the extracts was then mixed with wood paint 
without antifouling on wooden blocks. The concentration of antifouling paint treatment for each extract were $0 \mathrm{ppm}$, $250 \mathrm{ppm}, 500 \mathrm{ppm}, 750 \mathrm{ppm}$, and 1000 ppm.

\section{Work Procedure \\ Extraction of Test Materials}

The extraction method used was maceration, meanwhile, the kenikir ( $C$. caudatus) and bandotan (A. conyzoides) leaves were collected and cleaned with running water, and then dried. Afterward, the dried leaves were mashed using a blender until they become powder (simplicial). The simplicial was then soaked in $96 \%$ ethanol solvent with a ratio of 1: 4 for 24 hours, the filtrate obtained was macerated again thrice and concentrated in a rotary evaporator of BUCHI Rotavapor R-3 brand with a temperature of $70^{\circ} \mathrm{C}$ (Senja et al., 2014; Sari and Triyasmono, 2017).

\section{Phytochemical Analysis}

Phytochemical analysis on the bioactive compounds of kenikir ( $C$. caudatus) and bandotan (A. conyzoides) leaf extracts indicate several compounds including alkaloids, steroids/ triterpenoids, tannins, and saponins.

\section{Test Panel Preparation}

A test panel was prepared in form of a wooden block with a size of $7 \times 7 \mathrm{~cm}$ and a thickness of $2 \mathrm{~cm}$. Each block was given a hook hole to tie the nylon rope, strung horizontally, and was then painted using black oil paint treated with the test material based on the test concentration, namely 0 ppm, 250 ppm, 500 ppm, 750 ppm, and 1000 ppm.

\section{Trapping of Biofilm Bacteria}

The bacteria biofilm was trapped by submerging the test panel in water with a depth of about $30 \mathrm{~cm}$ from the surface for one week.

\section{Water Physical and Chemical Data}

The physical and chemical parameters of water observed include temperature, $\mathrm{pH}, \mathrm{TDS}$, and dissolved oxygen (DO). Observations are made every other day for one week.

\section{Isolation of Bacteria}

The bacteria were isolated by swabbing the surface of the test panel for each treatment concentration with an area of $3 \times 3 \mathrm{~cm}$ using a sterile cotton bud while the sample was put into a sterile bottle containing $100 \mathrm{ml}$ distilled water. Furthermore, media for bacteria culture was in form of MERCK nutrient agar with $23 \mathrm{~g}$ in $500 \mathrm{ml}$ of distilled water, thereafter, it was sterilized via autoclaving at $121^{\circ} \mathrm{C}$ for 15 minutes (Olsvik et al., 1994). Bacterial isolation from each sample was carried out in Duplo with dilution factors of $10^{-1}, 10^{-2}$, and $10^{-3}$ using the spread plate method on sterile petri dishes.

Bacterial samples were incubated at room temperature for $3 \times 24$ hours. The bacterial colonies on each plate were counted using the Total Plate Count (TPC) method. Meanwhile, bacterial colonies that appear visually were directly counted with the provisions of about $30-300$ colonies. Data on the number of colonies were recalculated using the Colony Forming Units (CFU's) formula (Fardiaz, 1989) as follows:

CFU's $/ \mathrm{ml}=\mathrm{n} \times \frac{1}{\text { delution factor }} \times \frac{1}{\text { spread plate }}$

Where:

$\mathrm{n} \quad=$ number of colonies

\section{Data Analysis}

The data analysis was carried out using a descriptive comparative method by observing the trend in the number of bacterial colonies in each extract treatment.

\section{RESULTS AND DISCUSSION}

Bacteria constitute one of several biofilm microbes, meanwhile, the freshwater biofilms generally consist of Proteobacteria, Bacteroidetes, and 
Cyanobacteria. Beta-Proteobacteria is a type of Proteobacteria that dominates biofilms in freshwater (Besemer, 2015; Romani, 2010). Besides, biofilm bacteria that stick to the substrate surface often trigger the attachment of other organisms. Bacterial biofouling tends to increase the process of destroying the substrate surface by increasing its "adsorbent" potential, hence the substrate experience faster corrosion (Characklis and Cooksey, 1993). Based on the observation on the number of bacterial colonies obtained after sample isolation, the number of bacterial colonies from kenikir leaf extract was less compared to the bandotan (Figure 1).

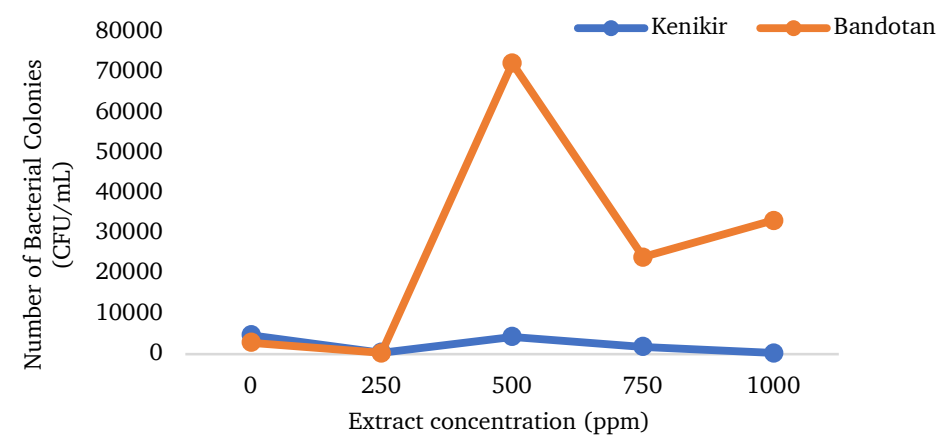

Figure 1. Number of microfouling bacterial colonies.

The number of bacteria in the kenikir leaf extract panel showed a lower yield which was more stable for all treatment concentrations compared to the bandotan leaf extract. The analysis results on the number of bacterial colonies with kenikir and bandotan leaf extracts are presented in Table 1. Furthermore, with the $96 \%$ ethanol maceration method, the concentration of kenikir leaf extract was effective at $250 \mathrm{ppm}$ and $1000 \mathrm{ppm}$ concentrations.

Kusuma et al. (2015), reported that the best kenikir leaf extract toxicity was obtained from $96 \%$ ethanol extract with 139 ppm reflux method and $70 \%$ ethanol extract with $142 \mathrm{ppm}$ maceration method. The 250-ppm concentration was closest to 142 ppm. Furthermore, Kusuma et al. (2015) also stated that a compound is declared to have acute toxicity when it has an $\mathrm{LC}_{50}$ value less than $1000 \mathrm{ppm}$. Therefore, kenikir leaf extracts at a concentration of $250 \mathrm{ppm}, 500 \mathrm{ppm}$, and $750 \mathrm{ppm}$ have toxic properties, meanwhile, the one with the highest bioactivity potential is at a concentration of $250 \mathrm{ppm}$.

Table 1. Result of analysis on number of bacterial colonies.

\begin{tabular}{ccccccccccc}
\hline $\begin{array}{c}\text { Extract } \\
\text { type }\end{array}$ & Concentration & Code & \multicolumn{3}{c}{ Dilution } & \multicolumn{2}{c}{$\begin{array}{c}\text { bacteria } \\
\text { types }\end{array}$} & Number of Colonies & $\begin{array}{c}\text { C Colonies } \\
\text { (cfu/ml) }\end{array}$ \\
& & & $10^{-1}$ & $10^{-2}$ & $10^{-3}$ & & $10^{-1}$ & $10^{-2}$ & $10^{-3}$ & \\
\hline Kenikir & $0 \mathrm{ppm}$ & K 0 & 127 & 8 & 12 & 2 & 1270 & 800 & 12000 & 4690 \\
& $250 \mathrm{ppm}$ & K 250 & 129 & 0 & 0 & 3 & 1290 & 0 & 0 & 430 \\
& $500 \mathrm{ppm}$ & K 500 & 84 & 20 & 10 & 1 & 840 & 2000 & 10000 & 4280 \\
& $750 \mathrm{ppm}$ & K 750 & 57 & 49 & 0 & 1 & 570 & 4900 & 0 & 1823 \\
& $1000 \mathrm{ppm}$ & K 1000 & 92 & 0 & 0 & 2 & 920 & 0 & 0 & 307 \\
Bandotan & $0 \mathrm{ppm}$ & B 0 & 91 & 76 & 0 & 1 & 910 & 7600 & 0 & 2837 \\
& $250 \mathrm{ppm}$ & B 250 & 9 & 9 & 0 & 2 & 90 & 900 & 0 & 330 \\
& $500 \mathrm{ppm}$ & B 500 & 6 & 43 & 212 & 1 & 60 & 4300 & 212000 & 72120 \\
& $750 \mathrm{ppm}$ & B 750 & 21 & 360 & 36 & 2 & 210 & 36000 & 36000 & 24070 \\
& $1000 \mathrm{ppm}$ & B 1000 & 352 & 18 & 94 & 2 & 3520 & 1800 & 94000 & 33107 \\
\hline
\end{tabular}


The total number of bacterial colonies on wood coated with kenikir leaf extract was less than bandotan because the macerated kenikir leaf extract with $96 \%$ ethanol has more effective bioactive compounds applicable as a coating mixture for antifouling substances. The effectiveness of kenikir leaf extract as an antifouling agent compared to bandotan is strengthened according to the results of phytochemical analysis shown in Table 2 .

Table 2. Phytochemical analysis results of kenikir and bandotan leaf extracts.

\begin{tabular}{lll}
\hline Bioactive Compounds & Kenikir Leaves & Bandotan Leaves \\
\hline Alkaloids & ++ & + \\
Steroids/Triterpenoids & + & + \\
Tannins & + & + \\
Saponins & + & + \\
\hline
\end{tabular}

Description: (-) there are no bioactive compounds

$(+)$ there are bioactive compounds

$(++)$ there are more bioactive compounds

Based on the phytochemical analysis of kenikir and bandotan leaf extracts obtained with $96 \%$ ethanol, both extracts were shown to contain active alkaloid compounds, steroids/triterpenoids, tannins, and saponins. Alkaloids are types of secondary alkaline metabolites in plants. It functions as a defense compound against pathogens and predators due to its toxicity. This toxic effect differs in each plant depending on the dosage, exposure time, and individual characteristics. Moreover, this compound disrupts the constituent of the bacterial cell wall (peptidoglycan) hence, causing death. Several studies have reported the use of alkaloids as anti-bacteria (Rahmawati et al., 2017; Puspitasari, 2016; Matsuura and Fett-Neto, 2015).

Kenikir and bandotan leaf extracts also contain steroids/triterpenoids, tannins, and saponins. Steroids/triterpenoids are potential antibacterial and anti-fungal, which destroys the structure of the bacterial cell wall and disrupts active transport as well as proton strength in the bacterial cytoplasmic membrane (Rahmawati et al., 2017; Dewi et al., 2012). Moreover, tannins also act as anti-fouling agents. This is in line with Idora et al. (2015) and Bellotti et al. (2012) which reported that tannin extract has an antifouling effect by inhibiting biofouling growth. Meanwhile, saponins are bioactive compounds that act as anti- bacterial due to the presence of an aglycone group. These compounds act by disrupting the permeability of bacterial cell membranes (Mengkido et al., 2019).

Based on the phytochemical analysis on kenikir and bandotan leaf extracts, research on the number of biofouling bacteria, as well as various references regarding the effectiveness of bioactive compounds as antibacterial, both extracts showed good potential as an antifouling agent. The potency of alkaloid bioactive compounds, steroids/triterpenoids, tannins, and saponins in inhibiting bacterial growth made these compounds functional antifouling agents. This is seen in the biofouling process which begins with bacterial growth on the substrate surface submerged in water, these bacteria then produce Extracellular Polymer Substances (EPS) to form biofilms (Characklis and Cooksey, 1983; Richard et al., 2017). Therefore, based on the antibacterial properties of kenikir and bandotan leaf extracts both are applicable as antifouling agents.

Based on the research results, the amount of alkaloid bioactive compounds in kenikir leaf extract was higher than bandotan. This was also supported by the smaller number of bacterial colonies in the kenikir leaf extract; hence this extract is more potent as an antifouling agent. This was supported by Rasdi et al. (2010) which stated that the phytochemical 
screening of $C$. caudatus leaf extract showed several compounds including terpenoids, flavonoids, alkaloids, tannins, and saponins in ethanol solvent. These results indicate the maximum number of bioactive compounds responsible for its potential as anti-microbial.

The ineffectiveness of the bandotan leaf extract as an antifouling agent is probably due to the inadequate eluent or solvent used. Solvent selection for the maceration process tends to be more effective when attention is paid to the solubility of the natural solvent compound (Radiena and Dompeipen, 2019). The solvent that effectively separates the bandotan leaf extract components is nhexane and ethyl acetate in the ratio of 2 : 1. This is based on the chromatographic profile (KLT) of this extract eluted with various solvent ratios. Meanwhile, in large amounts, bandotan leaf extract is more effective as an antifouling agent. This is in line with Mengkido et al. (2019) who stated that the higher the concentration of bandotan leaf extract as an anti-bacterial, the greater the inhibition power.

The observation results of water physical and chemical parameters are shown in Table 3 below:

Table 3. Observation results of water physical and chemical parameters.

\begin{tabular}{lccccc}
\hline \multicolumn{1}{c}{ Parameter } & \multirow{2}{*}{ Unit } & I & II & III & IV \\
\hline Temperature & ${ }^{\circ} \mathrm{C}$ & 27,9 & 22,9 & 24,6 & 26,0 \\
pH & - & 8,02 & 8,06 & 8,08 & 8,21 \\
Dissolved oxygen(DO) & $\mathrm{mg} / 1$ & 7,7 & 9,4 & 8,4 & 8,0 \\
TDS & $\mathrm{mg} / 1$ & 68 & 72 & 72 & 70 \\
\hline
\end{tabular}

Environmental factors including temperature and $\mathrm{pH}$ also influence the formation of biofilms. Temperature changes affect the structure of the bacterial colonies and the function of the biofilm. Furthermore, drastic changes in water temperature also affected the structure of the bacterial community meanwhile, $\mathrm{pH}$ also correlated with the composition of the biofouling bacterial community (Besemer, 2015). According to the observations on the water physical and chemical parameters, the temperature and dissolved oxygen values fluctuated, while the $\mathrm{pH}$ and TDS values were more stable. However, Romani (2010), reported that in contrast to biofilms in seawater, freshwater biofilms easily adapt to fluctuating temperatures, hence, the formation of these organisms is not affected.

\section{CONCLUSION}

Based on the results, the number of bacterial colonies on wood, coated with paint mixed with kenikir leaf extract was lesser compared to bandotan leaf extract. In addition, the phytochemical analysis showed that both extracts contain alkaloids, steroids, tannins and saponins, but the alkaloid content in kenikir leaf extract was higher than bandotan. Therefore, it was concluded that kenikir leaf extract is more suited as an alternative source of antifouling compared to bandotan due to the higher bioactive content, especially alkaloid compounds. The optimal concentration of kenikir leaf extract as an antifouling agent is $250 \mathrm{ppm}$ and $1000 \mathrm{ppm}$.

\section{ACKNOWLEDGMENT}

This research was funded by Jenderal Soedirman University, through the Beginner Lecturer Research Program for Fiscal Year 2020. The author is grateful to the Chairperson of the LPPM (Institute of Research and Community Service (LPPM), Dean of Faculty, Fisheries and Marine Sciences, Jenderal Soedirman University, and all parties involved in this research.

\section{REFERENCES}

Agostini, V.O., Macedo, A.J., Muxagata, E., da Silva, M.V. and Pinho, G.L.L., 
2020. Non-Toxic antifouling potential of caatinga plant extracts : effective inhibition of marine initial biofouling. Hydrobiologia, 847, pp.45-60. https://doi.org/10.1007/ s10750-019-04071-6

Aykin, E., Omuzbuken, B. and Kacar, A., 2019. Microfouling bacteria and the use of enzymes in eco-friendly antifouling technology. Journal of Coatings Technology and Research, 16, pp.847-856. https://doi.org/10. 1007/s11998-018-00161-7

Bellotti, N., del Amo, B. and Romagnoli, R., 2012. Caesalpinia spinosa tannin derivatives for antifouling formulations. Procedia Materials Science, 1, pp.259-265. Elsevier Ltd. Selection. https://doi.org/10.1016/ j.mspro.2012.06.035

Besemer, K., 2015. Biodiversity, community structure and function of biofilms in stream ecosystems. Europe PMC Funders Research in Microbiology, 166(10), pp.774-781. https://doi.org/10.1016/j.resmic.2 015.05.006

Characklis, W.G. and Cooksey, K.E., 1983. Biofilms and microbial fouling. Advances in Applied Microbiology, 29, pp.93-138. https://doi.org/10.1 016/S0065-2164(08)70355-1

Dewi, C.S.U., Soedharma, D. and Kawaroe, M., 2012. Phytochemical compound and toxicity of seagrass Enhalus acoroides and Thalassia hemprichii from Pramuka Island, DKI Jakarta. Jurnal Teknologi Perikanan dan Kelautan, 3(2), pp.23-27. https://doi.org/10.24319 /jtpk.3.23-27

Fardiaz, S., 1989. Petunjuk laboratorium analisis mikrobiologi pangan. IPB, Bogor, p. 121.

Fujita, D.S., Takeda, A.M., Coutinho, R. and Fernandes, F.C., 2015. Influence of antifouling paint on freshwater invertebrates (Mytilidae, Chironomidae and Naididae): density, richness and composition. Brazilian Journal of Biology, 75(4),
pp.S70-S78. https://doi.org/10.159 0/1519-6984.05114

Guardiola, F.A., Cuesta, A., Meseguer, J. and Esteban, M.A., 2012. Risk of using antifouling biocides in aquaculture. International Journal of Molecular Sciences, 13(2), pp.15411560. https://doi.org/10.3390/ijms 13021541

Idora, M.S.N., Ferry, M., Wan Nik, W.B. and Jasnizat, S., 2015. Evaluation of tannin from Rhizophora apiculata as natural antifouling agents in epoxy paint for marine application. Progress in Organic Coatings, 81, pp.125-131. https://doi.org/10.101 6/j.porgcoat.2014.12.012

Kusuma, I.J.D., Prasetyorini and Wardatun, S., 2015. Toksisitas ekstrak daun kenikir (Cosmos caudatus Kunth) dengan perbedaan metode dan jenis pelarut berbeda. JOM Bidang Farmasi, 1(1), pp.1-8. https://jom.unpak.ac.id/index.php/ Farmasi/article/view/705

Marhaeni, B., 2012. Biofouling pada beberapa jenis substrat permukaan kasar dan halus. Sains Akuatik: Jurnal Ilmiah Ilmu-Ilmu Perairan, 14(1), pp.41-47. http://jurnalnasio nal.ump.ac.id/index.php/AKUATIK /article/view/378

Matsuura, H.N. and Feet-Neto, A.G., 2015. Plant Alkaloids: Main Features, Toxicity, and Mechanisms of Action. In Gopalakrishnakone P., Carlini C., Ligabue-Braun R. (eds) Plant Toxins. Toxinology. Springer, Dordrecht. https://doi.org/10.1007/978-94-00 7-6464-4_2

Mengkido, M., Lambui, O. and Harso, W., 2019. Uji daya hambat ekstrak daun bandotan (Ageratum conyzoides L.) terhadap pertumbuhan bakteri Staphylococcus aureus. Biocelebes, 13(2), pp.121-130. https://bestjour nal.untad.ac.id/index.php/Bioceleb es/article/view/13575

Nakano, D. and Strayer, D.L., 2014. Biofouling animals in fresh water: biology, impacts, and ecosystem engineering. Frontiers in Ecology and 
the Environment, 12(3), pp.167-175. https://doi.org/10.1890/130071

Olsvik, O., Popovic, T., Skjerve, E., Cudjoe, K.S., Hornes, E., Ugelstad, J. and Uhlen, M., 1994. Magnetic separation techniques in diagnostic microbiology. Clinical Microbiology Reviews, 7(1), pp.43-54. https://doi. org/10.1128/cmr.7.1.43

Puspitasari, R., 2016. Evaluasi Penggunaan Ekstrak Lamun Sebagai Bahan Aktif Antifouling Terhadap Produsen Perairan. Jurnal Segara, 12(1), pp.45-51. http://dx.doi.org/ 10.15578/segara.v12i1.7654

Radiena, M.S.Y. and Dompeipen, E.J., 2019. Identifikasi senyawa aktif triterpenoid dari ekstrak alga laut hijau silpau (Dictyosphaeria versluysii) dengan spektrofotometer FTIR. Majalah BIAM, 15(1), pp.3340. http://dx.doi.org/10.29360/mb .v15i1.5297

Rahmawati, F., Bintang, M. and Artika, I.M., 2017. Antibacterial Activity and Phytochemical Analysis of Geranium homeanum Turez Leaves. Current Biochemistry, 4(3), pp.1322. https://jurnal.ipb.ac.id/index.p $\mathrm{hp} / \mathrm{cbj} /$ article/view/25431

Rasdi, N.H.M., Samah, O.A., Sule, A. and Ahmed, Q.U., 2010. Antimicrobial studies of Cosmos caudatus Kunth. (Compositae). Journal of Medicinal Plants Research, 4(8), pp.669-673. DOI: $10.5897 / J M P R 09.422$

Richard, C., Mitbavkar, S. and Landoulsi, J., 2017. Diagnosis of the diaton community upon biofilm Development on Stainless Steels in natural freshwater. Hindawi, 2017, pp.13. https://doi.org/10.1155/20 $17 / 5052646$

Roman1, A.M., 2010. Freshwater biofilms. Biofouling. Wiley-Blackwell, Oxford, pp.137-153. DOI: 10.1002/978144 4315462

Sari, D.I. and Triyasmono, L., 2017. Rendemen dan flavonoid total ekstrak etanol kulit batang bangkal (Nauclea subdita) dengan metode maserasi ultrasonikasi. Jurnal pharmascience, 4(1), pp.48-53. https ://doi.org/10.20527/jps.v4i1.5755

Senja, R.Y., Issusilaningtyas, E., Nugroho, A.K. and Setyowati, E.P., 2014. The comparison of extraction method and solvent variation on yield and antioxidant activity of Brassica oleracea L. var capitata f. rubra Extract. Traditional Medicine Journal, 19(1), pp.43-48. https://do i.org/10.22146/tradmedj.8090

Wells, S. and Sytsma, M., 2009. A review of the use of coatings to mitigate bofouling in freshwater. Portland State University, Center for Lakes and Reservoirs.

Yebra, D.M., Kiil, S. and Dam-Johansen, K., 2004. Antifouling technologypast, present and future steps towards efficient and environmentally friendly antifouling coatings. Progress in organic coatings, 50(20), pp.75-104. https:/ /doi.org/10.1016/j.porgcoat.2003. 06.001 